Jurnal Olahraga \& Kesehatan Indonesia

Volume 1 Nomor 2 (2021)

E-ISSN: 2747-061X

available online at https://jurnal.stokbinaguna.ac.id/index.php/jok

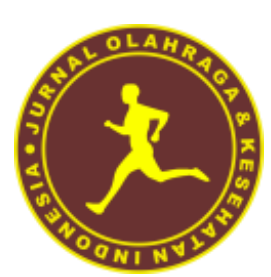

\title{
KONTRIBUSI LATIHAN CABLE CROSSOVER DAN PULL OVER TERHADAP JUMP SMASH BULU TANGKIS
}

\author{
Andi Mulawarman ${ }^{1}$, Taufik ${ }^{2} *$ \\ ${ }^{1}$ SMA N 13 Takalar, Sulawesi Selatan, Indonesia, 92254 \\ ${ }^{2}$ STKIP Muhammadiyah Barru, Sulawesi Selatan, Indonesia, 90761 \\ *Coressponding Author: upikunm@yahoo.com
}

\section{Keterangan}

Rekam Jejak:

Received, April 2021

Revised, Mei 2021

Accepted, Juni 2021

Kata Kunci:

Latihan Cross Over,

Latihan Pull Over, Jump

Smash Bulu Tangkis

Penelitian ini bertujuan Untuk mengetahui Secara keseluruhan, apakah bentuk latihan Cable Crossover dan bentuk latihan pullover memberikan pengaruh yang berbeda terhadap kemampuan Jumping Smash dalam permainan bulutangkis Mahasiswa UKM Olahraga STKIP Muhammadiyah Barru. Jenis penelitian ini adalah penelitian eskperimen dengan rancangan faktorial design $2 \times 2$. Populasinya adalah Mahasiswa UKM Olahraga STKIP Muhammadiyah Barru sebanyak 80 mahasiswa. Pemilihan sampel menggunakan teknik Random sampling dan menghasilkan 30 sampel. 30 sampel tersebut di acak kembali untuk menentukan 15 sampel masuk dalam kelompok metode latihan Cable Crossover dan 15 orang sampel lainnya masuk dalam kelompok metode latihan pullover. Kemudian diurut dari skor tertinggi sampai dengan skor terendah. Setiap kelompok metode latihan di ambil $27 \%=(4,05)$ dari 15 sampel dan dibulatkan menjadi 5 sampel. Hasil penelitian ini menunjukkan bahwa: Secara keseluruhan kemampuan Jumping Smash dalam permainan bulutangkis melalui bentuk latihan pullover lebih baik dari pada bentuk latihan Cable Crossover, terbukti dengan nilai rata-rata kelompok Latihan Crossover Power adalah 22,30, sedangkan untuk rata-rata kelompok Latihan Pullover adalah 24,30.
\end{abstract}




\section{Andi Mulawarman - Taufik}

upikunm@yahoo.com

\section{PENDAHULUAN}

Perkembangan dunia olahraga serta tuntutan peningkatan mutu atlet merupakan bagian dari dunia olahraga yang sangat penting bagi olahragawan. Mutu olahraga ditingkatkan untuk mengejar ketinggalan ilmu pengetahuan dan juga prestasi olahraga. Olahraga merupakan wahana yang paling efektif untuk memperkokoh persatuan dan kesatuan bangsa. Permainan Bulutangkis ini menjadi salah satu olahraga unggulan di Indonesia, tetapi prestasi olahraga ini makin lama makin merosot. Banyak faktor yang menyebabkan terjadinya kemerosotan prestasi bulutangkis tanah air. Kebutuhan fisik pada olahraga bulutangkis masa kini lebih menekankan pada komponen speed yang ekstra dan power.

Dengan adanya pandemi covid-19 ini dijadikan momen penting oleh mahasiswa dengan melakukan Latihan olahraga serta aktivitas fisik dirumah dengan melakukan gerakan kemampuan otot lengan dan otot tungkain . Virus Corona atau Covid-19 pertama kali ditemukan di Wuhan, China pada akhir Desember 2019. Penyebaran virus yang belum ditemukan penawarnya itu hingga kini tak terkendali. Sudah 200 lebih negara di dunia melapor adanya kasus terpapar virus Corona atau Covid-19. Di Indonesia kasus ini pertama kali ditemukan pada dua warga Depok, Jawa Barat awal Maret lalu. Data hingga Sabtu, 28 Maret 2020 jumlah warga yang dinyatakan positif terkena virus Corona mencapai 1.155 dan 102 diantaranya meninggal dunia. Cepatnya penyebaran virus ini di Indonesia menurut Juru bicara pemerintah untuk penanganan Covid-19, karena banyak warga yang tak mengikuti imbauan untuk tetap di rumah. Virus Corona menular lewat lendir (droplet) manusia positif Covid-19 bersin, batuk, atau berbicara lalu terkena orang lain yang negatif.

Setiap warga berperan untuk memutuskan mata rantai penyebaran virus Covid-19. Caranya seperti intruksi pemerintah, yakni: melakukan social distancing dan tidak keluar rumah. Bagi para pekerja diimbau untuk bekerja dari rumah atau work from home, dan bagi para pelajar/mahasiswa untuk melakukan kegiatan belajar dari rumah menggunakan teknologi berbasis online. Hanya kedua imbauan itu cenderung membuat orang kurang gerak. Studi menunjukkan bahwa kurang gerak dapat menurunkan daya tahan tubuh. Akibatnya, resiko terinfeksi virus Covid-19 justru menjadi lebih tinggi. Spesialis Kedokteran Olahraga menyarankan untuk tetap aktif selama tinggal di rumah. latihan fisik khususnya latihan kekuatan otot tungkai dan ototo lengan dengan intensitas sedang dapat menaikkan imunitas tubuh. Berolahraga atau melakukan aktivitas fisik lainnya bisa menjadi salah satu bagian pendukung untuk meningkatkan kekebalan atau meningkatkan imun kita .

Sistem imunitas tubuh yang dibutuhkan semua orang, terutama saat pandemi virus Corona atau Covid-19 seperti saat ini. masyarakat yang menghindari aktifitas fisik, serta pusat kebugaran yang menghindari pusat kebugaran karena khawatir penyakit virus masih memiliki berbagai pilihan olahaga yang bisa dilakukan di rumah tanpa peralatan khusus. Mahasiswa STKIP muhammadiyah barru prodi bimbingan dan koseling dengan ada nya covid 19 ini melakukan kuliah dengan metode during dari setiap dosen dan kulaih praktek serta kuliah teori dilakukan dirumah secara during kemudian mahasiswa dituntun untuk hidup sehat dan tetap menjalankan aktivtas dan menjaga bugar dengan melaksanakan aktivitas fisik selama kuliah daring. Dari hasil pengamatan tersebut, bahwa sangat pentingnya aktivitas fisik khususnya aktivitas fisik latihan kekuatan otot, baik itu kekuatan otot tungkai maupun ototlengan serta latihan fifik lainnya. Bagi mahasiswa yang masuk dalam unit kegiatan mahasiswa (UKM) Olahraga di kampuas STKIP Muhammadiyah Barru dengan Latihan olahraga Bulutangkis serta menjaga bugar tubuh selama covid dan pademi ini. "Fokus pada dasar-dasar gerakan olahraga bulutangkis seperti, latihan kekuatan otot tungkai dan kekuatan ototo lengan , untuk latihan standar, yang akan membangun kekuatan dan meningkatkan detak jantung. Pilih latihan yang menjangkau berbagai area tubuh dan lakukan latihan keseluruhan sekitar 20 menit".

Tubuh yang sehat merupakan faktor yang sangat penting dalam aktifitas fisik dalam olahraga bulutangkis di masa pandemic covid-19. Karena bila tubuh tidak sehat segala aktivitas 


\section{Andi Mulawarman - Taufik}

upikunm@yahoo.com

termasuk kegiatan latihan kondisi fisik tidak akan berjalan dengan maksimal. Sedangkan bila memiliki tubuh sehat segala aktivitas atau latihan akan dapat dilakukan dengan baik. Di dalam berolahraga khususnya olahrga bulutangkis di masa pandemic covid-19 ini ,kekuatan otot merupakan kemampuan seseorang dalam melakukan aktivitas sehari-hari tanpa menimbulkan kelelahan yang berlebihan.

Selama berlangsungnya pandemi Covid-19 menjaga perilaku hidup sehat sangatlah penting. Penerapan gaya hidup sehat secara individu seperti rutin berolahraga, mengonsumsi makanan bergizi, tidur cukup, dan mengelola stres dengan baik. Olahraga bulutangkis dapat membantu seseorang untuk memperbaiki imunitas, mempertahankan kondisi fisik dan membantu untuk meminimalisir stress jika dilaksanakan memperhatikan prinsip frequency, intensity, time, dan type. Anjuran melakukan olahraga juga tidak hanya terbatas pada masyarakat ketika tidak sedang bekerja. Pada masyarakat yang terpaksa tidak bisa melakukan pekerjaan dari rumah juga diminta untuk berolahraga. Terdapat peraturan khusus yang mewajibkan tempat kerja untuk memberikan kesempatan menjaga kesehatan fisik dengan melakukan olahraga seperti olahrga bulutangkis dimana olahraga ini di laksanakan dengan jarak tertentu tanpa ada sentuhan fisik sesame pemain, dimana anjuran pemerintah yang menyarankan agar selalu menjaga jarak atau kontak fisik.

Guna mendukung peningkatan prestasi olahraga bulutangkis tidak lepas dari proses pembinaan seorang atlet terutama dalam hal kondisi fisik pemain bulutangkis. Pembinaan olahraga bulutangkis yang terprogram secara khusus, disamping mengandalkan keterampilan bermain juga mempertimbangkan kondisi fisik para atlet. Karena kondisi fisik merupakan landasan bagi aspek-aspek lain, seperti teknik, taktik dan mental. Maka seorang pemain bulutangkis harus memiliki kualitas fisik yang baik sesuai dengan kebutuhan pemain bulutangkis. Seorang atlet bulutangkis sangat penting memiliki derajat kondisi fisik prima, sebab peningkatan kondisi fisik bertujuan menunjang aktivitas olahraga dalam rangka mencapai prestasi prima. Melalui proses latihan fisik yang terprogram baik, pebulutangkis harus memiliki kualitas kebugaran jasmani yang berdampak positif pada kebugaran mental, psikis, yang akhirnya berpengaruh langsung pada penampilan teknik bermain. Karena dengan mental yang baik seorang atlet akan dapat meraih prestasi yang maksimal. Olahragawan dikatakan siap mentalnya manakala olahragawan tersebut tidak merasa tertekan, takut, khawatir, dan perasaan negatif lainnya.

Beberapa komponen fisik yang menentukan kebugaran jasmani seorang atlet yaitu kelentukan, daya tahan, kecepatan, kekuatan, dan kekuatan yang cepat 'speed strength' Semua komponen kondisi fisik yang telah disebutkan sangat mendukung untuk melakukan gerakangerakan dalam bermain bulutangkis. Power pada penelitian ini difokuskan pada power otot tungkai dan kekutan lengan yang meliputi beberapa otot pendukung dalam melakukan pukulan jumping smash. Menurut jurnal china dikatakan bahwa, ada beberapa otot yang menunjang dalam gerakan jumping smash diantaranya pada bagian ekstremitas atas yaitu pergelangan tangan yaitu gerakan fleksi dan ekstensi, trisep, deltoid dan pectoralis major menurut pendapat para ahli. Hasil dari pernyataan di atas penulis lebih memfokuskan maksud dari penelitian ini pada latihan power otot tungkai dan kekuatan lengan dalam melakukan pukulan jumping smash.

Dari beberapa aspek latihan yang diperlukan, masalah disini lebih menekankan pada latihan fisik yaitu latihan kekuatan lengan dan power otot tungkai. Latihan kekuatan dilakukan dengan irama sedang, sedangkan latihan power ini dilakukan dengan latihan gerakan cepat. Karena latihan ini bertujuan untuk meningkatkan kekuatan lengan dan power otot tungkai yang disesuaikan terhadap otot-otot yang mendukung terjadinya pukulan jumping smash. Jumping smash bulutangkis merupakan pukulan offensive yang paling kuat di bulutangkis. Pukulan ini sering digunakan oleh pemain ganda, akan tetapi pemain tunggal pun membutuhkan pukulan ini meski takarannya lebih banyak di ganda. Pelaksanaan pukulan jumping smash memerlukan sebuah gerakan koordinasi yang komplek, gerakan-gerakan itu salah satunya dari faktor 


\section{Andi Mulawarman - Taufik}

upikunm@yahoo.com

kekuatan lengan dan power otot tungkai yang nantinya akan memberikan pengaruh terhadap hasil ketepatan pukulan.

Berangkat dari fenomena semacam ini kondisi dilapangan, peneliti mencoba mengedepankan sebuah permasalahan yang nantinya diharapkan dapat memberikan sebuah kontribusi dalam penerapan fisik khususnya latihan beban baik kepada pelatih maupun atlet. Dari uraian di atas, peneliti dapat mengedepankan rumusan masalah yang nantinya untuk dijawab dalam sebuah penelitian dan pengukuran dilapangan adalah sebagai berikut "Pengaruh Metode Latihan Kekuatan otot terhadap Kemampuan Jumping Smash dalam Permainan Bulutangkis.

Menurut (Poole, 2004). Permainan bulutangkis merupakan permainan yang dimainkan oleh masing-masing satu pemain di satu sisi pada permainan tunggal, dan masing-masing dua pemain di satu sisi pada permainan ganda. Sedangkan menurut (Juang, 2015) bulutangkis merupakan olahraga yang menggunakan raket dan shuttlecock dengan ritme permainan yang bervariasi dari lambat hingga cepat yang disertai gerak mengecoh atau tipuan sehingga permainan ini membutuhkan kecepatan, fleksibilitas dan kelincahan.

Senada dengan diatas ( Amir Fattahudin, dkk, 2020) Olahraga bulutangkis adalah olahraga yang mendunia, bahkan banyak kalangan masyarakat yang menggemari bulutangkis saat ini. Terbukti dengan banyaknya klub kecil yang ada di desa-desa dengan sampai klub besar yang ada di kota-kota serta turut memberikan beasiswa tersendiri untuk atlet yang memiliki prestasi tersendiri. Bulutangkis merupakan olahraga yang praktis dan simpel yang bisa dilakukan dimana saja.

Sistem yang berlaku saat ini dalam permainan bulutangkis adalah sistem reli 21 poin (Kurniawan, 2011). Maksud dari sistem rally point yaitu permainan ini dilakukan setiap set dengan skor game 21 poin dan cara penghitungan yaitu setiap seorang melakukan kesalahan, lawan langsung memperoleh poin. Seorang atau sepasang pemain akan dinyatakan menang dalam pertandingan bila telah memenangkan dua set permainan. Pemain yang mampu memenangkan lebih dahulu 2 set pertandingan akan dinyatakan sebagai pemenang (Alhusin, 2002). Batas maksimal dalam sebuah pertandingan yaitu 3 set, pertandingan ini bisa terjadi apabila para pemain sama-sama memenangkan 1 set dalam permainannya.

Penyakit virus corona atau covid-19 adalah penyakit menular yang disebabkan oleh virus corona yang baru baru ini ditemukan. Sebagian besar orang yang tertular covid-19 akan mengalami gejala ringan hingga sedang, dan akan pulih tanpa penanganan khusus. Virus yang menyebabkan covid-19 terutama ditransmisikan melalui droplet (percikan air liur) yang di hasilkan saat orang yang terinfeksi batuk, bersin, atau menembuskan nafas. Droplet ini terlalu berat dan tidak bisabertahan di udara, sehingga dengan cepat jatuh dan menempel pada lantai atau permukaan lainnya. Anda dapat tertular saat menghirup udara yang mengandung virus jika anda berada terlalu dekat dengan orang yang sudah terinfeksi covid-19.anda juga dapat tertular jika menyentuh mata, hidung, atau mulut anda.

Menurut (Sukadiyanto, 2011) Latihan atau training adalah penerapan dari suatu perencanaan untuk meningkatkan kemampuan berolahraga yang berisikan materi teori dan praktek, metode, dan aturan pelaksanaan sesuai dengan tujuan dan sasaran yang akan dicapai. Sedangkan Menurut (Hardiansyah, 2017) latihan merupakan aktivitias yang dilakukan secara berulang dengan suatu tujuan. Tujuan dari latihan itu sendiri adalah untuk menigkatkan kemampuan. Menurut (Kristiawan, 2016) latihan adalah hal yang penting untuk mengembangkan pengetahuan dengan mengikuti instruksi yang diberikan yang akan mengubah pengetahuan deklaratif (mengetahui apa yang harus dilakukan) hingga pengetahuan prosedural (mengembangkan kemampuan untuk melakukan tugas). Menurut Sukadiyanto (2011) tujuan latihan secara umum adalah untuk membantu para pembina, pelatih, guru olahraga agar dapat menerapkan dan memiliki kemampuan secara konseptual serta keterampilan dalam membantu mengungkapkan potensi olahragawan mencapai puncak. Menurut (Nursyam, 2016) Tujuan 


\section{Andi Mulawarman - Taufik}

upikunm@yahoo.com

latihan adalah untuk mengarahkan atlet ke arah yang lebih baik, yaitu dengan memperbaiki keterampilan yang dimiliki oleh atlet sesuai dengan spesialisasi cabang olahraganya.

Menurut (Harsono,1988), mengemukakan bahwa: "Kekuatan adalah kemampuan otot untuk membangkitkan tegangan terhadap suatu tahanan". Sedangkan menurut (Sajoto, 1988), mengemukakan bahwa : "Kekuatan adalah komponen fisik yang menyangkut kemampuan seorang atlet pada saat mempergunakan otot-ototnya menerima beban dalam waktu kerja tersebut ". Menurut (Yusuf, 2015). Kekuatan otot lengan dibutuhkan sebagai tenaga pendorong pada saat melakukan pukulan. Semakin besar kekuatan otot lengan yang dihasilkan maka semakin keras pula pukulan yang dihasilkan. Sedangkan Muliadi Muin (2019) Kekuatan otot lengan adalah kemampuan seseorang dalam mempergunakan kekuatan maksimal dari otot lengan dalam mengeluarkan seluruh potensi atau kekuatan yang ada pada periode yang singkat.

Menurut (Nursyam, 2016). Power otot merupakan komponen biomotorik yang diperlukan oleh semua atlet, dengan kadar tingkatan yang berbeda satu dengan yang lainnya. Power otot merupakan suatu kemampuan sistem neuromuskular dalam menghasilkan gaya, kekuatan dan kecepatan. Sedangkan menurut (Sukadiyanto, 2011). Power adalah hasil kali antara kekuatan dan kecepatan. Untuk itu, urutan latihan untuk meningkatkan power diberikan setelah olahragawan dilatih unsur kekuatan dan kecepatan. Pada dasarnya setiap bentuk dari latihan kekuatan dan kecepatan kedua-duanya selalu melibatkan unsur power. Menurut (Arisman, dkk, 2018) menjelaskan pukulan smash dalam bulutangkis merupakan pukulan tercepat dari olahraga raket lainnya. Sedangkan menurut (Prayadi \& Rachman , 2013) menjelaskan bahwa pukulan smash merupakan pukulan yang dilakukan dengan memukul shuttlecock dari atas kepala di arahkan ke bawah menuju lapangan lawan dan dilakukan dengan tenaga penuh. Lebih lanjut (Juang, B.R, 2015) mengemukakan bahwa pukulan smash merupakan pukulan yang paling kuat dan yang paling keras.

\section{METODE}

Penelitian ini menggunakan pendekatan kuantitatif dengan jenis eksperimen. Penelitian eksperimen memiliki tujuanyang dikemukakan oleh (Narbuko \& Achmadi , 2015) yaitu untuk menyelidiki kemungkinan saling hubungan sebab akibat dengan cara mengenakan kepada satu atau lebih kelompok eksperimen, satu atau lebih kondisi perlakuan dan membandingkan hasilnya. Populasi pada penelitian ini adalah Mahasiswa yang masuk UKM Olahraga STKIP Muhammadiyah Barru sebanyak 80 orang mahasiswa yang terdiri dari beberapa jurusan. Penelitian ini menggunakan mahasiswa yang mempunyai teknik tinggi dalam bermain bulutangkis, khususnya dalam hal melakukan pukulan jumping smash. Maka dari itu, perlu dilakukan pengambilan sampel dengan menggunakan metode Random Sampling. Dimana menurut (Sugiyono, 2015) Random Sampling adalah teknik penentuan sampel dilakukan secara acak tanpa memperhatikan starata yang ada dalam populasi itu. Sampel dalam penelitian ini adalah mahasiswa Yang masuk UKM olahraga STKIP Muhammadiyah Barru yang berjumlah 30 orang. Teknik analisis data yang digunakan dalam penelitian adalah Uji asumsi statistik meliputi uji normalitas data dan uji homogenitas. Uji normalitas dilakukan untuk mengetahui bentuk distribusi data yang diperoleh sebagai syarat awal untuk pengujian parametrik selanjutnya. Uji normalitas ini juga dilakukan sebagai upaya untuk memenuhi syarat penarikan kesimpulan yang bersifat baku dan handal, untuk dapat digeneralisasikan.

\section{HASIL \& PEMBAHASAN}

Data yang diperoleh dalam penelitian ini adalah data tes pukulan jumping smash Mahasiswa UKM Olahraga STKIP Muhammadiyah Barru, oleh (1) kelompok metode latihan Cable Crossover dengan power otot tungkai tinggi, (2) kelompok metode latihan pullover dengan power otot tungkai tinggi, (3) kelompok metode latihan Cable Crossover dengan power otot tungkai rendah, (4) kelompok metode latihan pullover dengan power otot tungkai rendah, 


\section{Andi Mulawarman - Taufik}

upikunm@yahoo.com

dari total 20 jumlah sampel. Adapun pemaparan data deskriptif di uraikan dalam tabel berikut ini:

Tabel 1. Data Hasil Tes Jump Smash

\begin{tabular}{cccc} 
& & \multicolumn{2}{c}{ Power Otot Tungkai } \\
& & Power Otot Tungkai & Power Otot Tungkai \\
Latihan Kekuatan & Latihan Crossover & Rendah & Tinggi \\
Lengan & Latihan Pullover & 19.40 & 25.20 \\
\hline
\end{tabular}

Berdasarkan pada tabel 1 di atas, maka hasil analisis deskriptif pada penelitian ini dapat di interpretasikan sebagai berikut:

- Diketahui bahwa rata-rata pada kelompok Latihan Crossover Power Otot Tungkai Rendah adalah 19,40, sedangkan untuk kelompok Latihan Crossover Power Otot Tungkai Tinggi adalah 25,20. Untuk rata-rata pada kelompok Latihan Pullover Power Otot Tungkai Rendah adalah 25,60, sedangkan untuk kelompok Latihan Pullover Power Otot Tungkai Tinggi adalah 23,00. Sehingga dapat kita ambil kesimpulan bahwa rata-rata Latihan Kekuatan Lengan pada kelompok Latihan Pullover lebih besar dibandingkan dengan rata-rata kelompok Latihan Crossover.

- Untuk nilai rata-rata setiap kelompok, dapat diketahui bahwa kelompok Latihan Crossover Power Otot Tungkai Rendah adalah 19,40 sedangkan pada kelompok Latihan Pullover Power Otot Tungkai Rendah adalah 25,60 maka dapat disimpulkan bahwa Latihan Pullover lebih cocok digunakan untuk atlet/sampel yang memiliki Power Otot Tungkai Rendah dibandingkan Latihan Crossover.

- Untuk nilai rata-rata setiap kelompok, dapat diketahui bahwa kelompok Latihan Crossover Power Otot Tungkai Tinggi adalah 25,20 sedangkan pada kelompok Latihan Pullover Power Otot Tungkai Tinggi adalah 23,00 maka dapat disimpulkan bahwa Latihan Crossover lebih cocok digunakan untuk atlet/sampel yang memiliki Power Otot Tungkai Tinggi dibandingkan Latihan Pullover.

Sebelum dilakukan analisis data perlu di uji distribusi normal. Uji Normalitas data dalam penelitian ini menggunakan uji Kormogrov-Smirnov Z lebih besar dari nilai $\alpha 0,05$ atau taraf signifikansi $95 \%$.. Hal ini dikarenakan suatu data dalam sebuah penelitian yang akan dianalisis secara statistik harus memenuhi syarat-syarat analisis.

Tabel 2. Rangkuman Uji Normalitas

\begin{tabular}{cccc}
\hline Variabel & \multicolumn{3}{c}{ Kolmogorov-Smirnov $^{\mathrm{a}}$} \\
\cline { 2 - 4 } Latihan Crossover Power Otot Tungkai Rendah & Statistic & Df & Sig. \\
Latihan Crossover Power Otot Tungkai Tinggi & .313 & 5 & .124 \\
Latihan Pullover Power Otot Tungkai Rendah & .221 & 5 & $.200^{*}$ \\
Latihan Pullover Power Otot Tungkai Tinggi & .198 & 5 & $.200^{*}$ \\
\hline
\end{tabular}

Berdasarkan tabel 2 tentang uji normalitas data berdasarkan tes awal pukulan jumping smash Mahasiswa UKM Olahraga STKIP Muhammadiyah Barru dapat dijabarkan sebagai berikut:

- Kelompok Latihan Crossover Power Otot Tungkai Rendah, dengan jumlah sampel 5 diperoleh nilai Kolmogrov-Smirnov Z (K-SZ) sebesar $0.124(0.124>0,05)$, hal ini menunjukkan bahwa data tes pukulan jumping smash Mahasiswa UKM Olahraga STKIP Muhammadiyah Barru pada kelompok Latihan Crossover Power Otot Tungkai Rendah berdistribusi normal.

- Kelompok Latihan Crossover Power Otot Tungkai Tinggi, dengan jumlah sampel 5 diperoleh nilai Kolmogrov-Smirnov Z (K-SZ) sebesar $0.200^{*}\left(0.200^{*}>0,05\right)$, hal ini 


\section{Andi Mulawarman - Taufik}

upikunm@yahoo.com

menunjukkan bahwa data tes pukulan jumping smash Mahasiswa UKM Olahraga STKIP Muhammadiyah Barru pada kelompok Latihan Crossover Power Otot Tungkai Tinggi berdistribusi normal.

- Kelompok Latihan Pullover Power Otot Tungkai Rendah, dengan jumlah sampel 5 diperoleh nilai Kolmogrov-Smirnov Z (K-SZ) sebesar $0.200^{*}\left(0.200^{*}>0,05\right)$, hal ini menunjukkan bahwa data tes pukulan jumping smash Mahasiswa UKM Olahraga STKIP Muhammadiyah Barru pada kelompok Latihan Pullover Power Otot Tungkai Rendah berdistribusi normal.

- Kelompok Latihan Pullover Power Otot Tungkai Tinggi, dengan jumlah sampel 5 diperoleh nilai Kolmogrov-Smirnov Z (K-SZ) sebesar $0.200^{*}\left(0.200^{*}>0,05\right)$, hal ini menunjukkan bahwa data tes pukulan jumping smash Mahasiswa UKM Olahraga STKIP Muhammadiyah Barru pada kelompok Latihan Pullover Power Otot Tungkai Rendah berdistribusi normal.

Uji homogenitas merupakan untuk menguji kesamaan varians antara (1) kelompok metode latihan Cable Crossover dengan power otot tungkai tinggi, (2) kelompok metode latihan pullover dengan power otot tungkai tinggi, (3) kelompok metode latihan Cable Crossover dengan power otot tungkai rendah, (4) kelompok metode latihan pullover dengan power otot tungkai rendah, pukulan jumping smash Mahasiswa UKM Olahraga STKIP Muhammadiyah Barru, Uji homogenitas ini berfungsi sebagai persyaratan dalam pengujian sampel dari populasi yang homogen.

Tabel 3. Rangkuman Uji Homogenitas

\begin{tabular}{|c|c|c|c|c|}
\hline Pukulan Jump Smash & $\begin{array}{l}\text { Levene } \\
\text { Statistik }\end{array}$ & Dfl & $\mathrm{dfl} 2$ & Sig \\
\hline $\begin{array}{c}\text { (1) kelompok metode latihan Cable Crossover dengan } \\
\text { power otot tungkai tinggi, } \\
\text { (2) kelompok metode latihan pullover dengan power otot } \\
\text { tungkai tinggi, } \\
\text { (3) kelompok metode latihan Cable Crossover dengan } \\
\text { power otot tungkai rendah, } \\
\text { (4) kelompok metode latihan pullover dengan power otot } \\
\text { tungkai rendah. }\end{array}$ & 0.037 & 2 & 42 & 0.164 \\
\hline
\end{tabular}

Berdasarkan tabel 3 tentang uji homogenitas data (1) kelompok metode latihan Cable Crossover dengan power otot tungkai tinggi, (2) kelompok metode latihan pullover dengan power otot tungkai tinggi, (3) kelompok metode latihan Cable Crossover dengan power otot tungkai rendah, (4) kelompok metode latihan pullover dengan power otot tungkai rendah untuk pukulan jumping smash Mahasiswa UKM Olahraga STKIP Muhammadiyah Barru dengan Levene Test adalah 0.037 dengan nilai Sig 0.164. Karena nilai probabilitas lebih besar dari $\alpha$ 0.05 atau taraf signifika 95\%, maka dari itu (1) kelompok metode latihan Cable Crossover dengan power otot tungkai tinggi, (2) kelompok metode latihan pullover dengan power otot tungkai tinggi, (3) kelompok metode latihan Cable Crossover dengan power otot tungkai rendah, (4) kelompok metode latihan pullover dengan power otot tungkai rendah terhadap pukulan jumping smash Mahasiswa UKM Olahraga STKIP Muhammadiyah Barru bagi keempat kelompok latihan adalah homogen atau berasal dari kelompok yang sama.

Pengujian hipotesis dilakukan dengan menggunakan analisis ANCOVA Faktorial. Dalam pengujian dengan ANCOVA Faktorial, skor tes dijadikan sebagai dependent variabel. Nilai ini menunjukkan berapa besar pengaruh variabel dependen, signifikan $<0,05$ berarti pengaruh signifikan. Berikut adalah hasil uji data penelitian: 
Tabel 4. Rangkuman Analisis ANCOVA Factorial

\begin{tabular}{cccccc}
\hline Source & Type III Sum of & df & Mean Square & F & Sig. \\
Corrected Model & Squares & & & & \\
Intercept & $121.000^{\mathrm{a}}$ & 3 & 40.333 & 22.100 & .000 \\
Latihan Kekuatan Lengan & 10857.800 & 1 & 10857.800 & 5949.479 & .000 \\
Power Otot Tungkai & 12.800 & 1 & 12.800 & 7.014 & .018 \\
Latihan Kekuatan Lengan * X2 Otot Tungkai & 20.000 & 1 & 20.000 & 10.959 & .004 \\
Error & 88.200 & 1 & 88.200 & 48.329 & .000 \\
Total & 29.200 & 16 & 1.825 & & \\
Corrected Total & 11008.000 & 20 & & \\
R Squared $=.806$ (Adjusted R Squared =.769) \\
\hline
\end{tabular}

Dari tabel 4 di atas dapat diketahui beberapa hasil, adapun interpretasi dari tabel tersebut antara lain; latihan kekuatan lengan dalam hal ini latihan Cable Crossover dan latihan pullover dapat diketahui bahwa nilai Sig. 0,018<0,05, power otot tungkai dapat diketahui bahwa nilai Sig. $0,004<0,05$.

\section{SIMPULAN}

Berdasarkan hasil analisa dari penelitian dan pembahasan yang telah diungkap dalam penelitian ini, maka dapat disimpulkan bahwa: 1). Secara keseluruhan, kemampuan Jumping Smash dalam permainan bulutangkis dimasa pandemik covid-19 melalui bentuk latihan pullover lebih baik dari pada bentuk latihan Cable Crossover. 2). Terdapat interaksi antara bentuk latihan kekuatan lengan dengan Power otot tungkai terhadap kemampuan Jumping Smash di masa pandemik covid-19 dalam permainan bulutangkis. 3). Bagi mahasiswa yang memiliki Power otot tungkai tinggi, kemampuan Jumping Smash dimasa pandemik covid-19 dalam permainan bulutangkis melalui bentuk latihan Cable Crossover lebih baik dari pada bentuk latihan pullover. 4). Bagi mahasiswa yang memiliki Power otot tungkai rendah, kemampuan Jumping Smash dimasa pandemik covid-19 dalam permainan bulutangkis melalui bentuk latihan pullover lebih baik dari pada bentuk latihan Cable Crossover.

\section{DAFTAR PUSTAKA}

Arisman, A., \& Saripin, S. (2018). Hubungan kelentukan pergelangan tangan dan power otot lengan-bahu dengan hasil akurasi smash bulutangkis putra pada PB Angkasa Pekanbaru. Journal of Sport Education, 1(1), 9-16.

Hardiansyah, S. (2017). The Influence Of Circuit Training Method On The Enhancement Of Physical Fitness Of Sports Education Department Students. Proceedings The 1st Yogyakarta international seminar on health, physical education, and sports science.

Harsono. (1988). Coaching dan Aspek-Aspek Psikologis dalam Coaching. Jakarta: Depdikbud Dirjen Dikti PPLTK.

Juang, B R. (2015). Analisis Kelebihan dan Kelemahan Keterampilan Teknik Bermain Bulutangkis pada Pemain Tunggal Putra Terbaik Indonesia Tahun 2014. Jurnal Kesehatan Olahraga, 3(1).

Karyanto. (2012). Pengaruh Pembelajaran Net Game Terhadap Peningkatan Keterampilan Passing Atas Bola Voli Mini Bagi Siswa Kelas V SDB 3 Prambanan Klaten. Artikel E-journal (online) Universitas Negeri Yogyakarta.

Kristiawan, Agung., \& Sukadiyanto. (2016). Pengaruh metode latihan dan koordinasi terhadap smash backcourt. Jurnal Ilmu Keolahragaan, 4 ( 2), 122- 134.

Mohammad, Amir Fattahudin, \& Oni Bagus Januarto, Gema Fitriady. (2020). Upaya Meningkatkan Keterampilan Pukulan Forehand Smash Bulutangkis Dengan 


\title{
Andi Mulawarman - Taufik
}

\author{
upikunm@yahoo.com
}

Menggunakan Model Variasi Latihan Untuk Atlet Usia 12-16 Tahun. Jurnal Sport Science and Health, 2(3).

Muliadi, Muin. (2019). Analisis Kondisi Fisik Atlit Pomnas Cabang Olahraga Bulutangkis Maluku Utara Tahun 2019. Jurnal Pendidikan Mandala

Narbuko, Cholid \& Achmadi, Abu.( 2015). Metodologi Penelitian . Jakarta :PT Bumi aksara

Nursyam . (2016). Pengaruh kekuatan lengan dan Power Otot Tungkai terhadap Kemampuan Jumping Smash dalam Permainan Bulutangkis terhadap Mahasiswa FIK UNM. Universitas Negeri Makassar.

Prayadi, HY., \& Rachman, H A. (2013). Pengaruh Metode Latihan Dan Power Lengan Terhadap Kemampuan Smash Bulutangkis. Jurnal Keolahragaan, 1(1), 63-71.

Sajoto. (1988). Pembinaan Kondisi Fisik dalam Olahraga. Jakarta: Depdikbud.

Sugiyono. (2015). Metode Penelitian Pendidikan. Bandung: Alfabeta.

Sukadiyanto. (2011). Pengantar Teori dan Metodologi Melatih Fisik. Yogyakarta: CV Lubuk Agung.

Suryabrata, Sumadi. (2014). Metodologi Penelitian. Jakarta: Rajawali.

Yusuf, Ahmad., dkk. (2015). Buku Ajar Keperawatan Kesehatan Jiwa. Jakarta: Salemba Medika. 